\title{
Recurring Armed Conflict in the Eastern Democratic Republic of Congo: an Insight into the SADC Intervention Problematique
}

\author{
Sadiki Maeresera \& Knocks Tapiwa Zengeni \\ University of KwaZulu-Natal's School of Social Sciences, South Africa \\ School of International Studies, Universiti Utara Malaysia, Malaysia \\ sadikimm@yahoo.com,knocks@uum.edu.my \\ DOI: https://doi.org/10.32890/jis2017.13.10
}

\begin{abstract}
Conflict recurrence in the eastern Democratic Republic of Congo (DRC) provides a litmus test to the Southern African Development Community's (SADC's) capacity to sustainably resolve the conflict and build peace. The surrender of the March 23 (M23) rebels, followed by overtures to incorporate the same into the Congolese military and political institutions, seem not to have made much significant impact on the security stability in the eastern part of the country. Armed activities by militia groups such as the Democratic Liberation Forces of Rwanda (FDLR), the Allied Democratic Forces (ADF), the Lord's Resistance Army (LRA), and various Mayi Mayi groups are likely to cause a recurrence of a fully fledged armed conflict in eastern Congo. Whilst the UN Mission for the Stabilisation of Congo (MONUSCO), along with its Intervention Brigade continue to make efforts to support the Congolese government to address the security situation in the country, this article presents a critical analysis on the prospects and constraints of SADC to sustainably resolve the conflict and build peace in the context of conflict recurrence. For purposes of conflict resolution and peacebuilding, the DRC falls within SADC's area of sub-regional responsibility, which overlaps that of the International Conference of the Great Lakes Region (ICGLR). The paper looks at the political/diplomatic and military/ security initiatives that SADC can take to complement the current efforts of critical role players such as MONUSCO and ICGLR in sustainably resolving the recurring conflict and building peace.It also analyses the prospects of such sub-regional initiatives. Considering the conflict matrix of the eastern Congo conflict with specific reference to its recurrence, an examination of the likely constraints that SADC could encounter in trying to resolve the eastern Congo conflict will be presented. Policy suggestions will be proffered on what can be done to encounter such constraints. The research adopted a qualitative approach premised on interviews. Secondary sources, including key policy documents and statements of the SADC, AU, ICGLR and UN, were utilised. To complement the primary sources, structured opportunity interviews were conducted at seminars and workshops with academics and senior political and security analysts conversant with the SADC conflict and peace dynamics.
\end{abstract}

Keywords: Conflict recurrence, Southern African Development Community, political security, military security. 


\section{Introduction}

Conflict recurrence in the Democratic Republic of Congo (DRC), and more specifically the eastern DRC, is not a new phenomenon. For almost two decades, activities by different armed groups have had devastating effects on the Congolese populace, ranging from the killing of a significant number of innocent civilians, mainly women and children, to innumerable cases of rape, the forcible recruitment of child soldiers, and the displacement of over half a million people. Diplomatic/Political and military/security efforts have been undertaken by various actors at sub-regional, regional and international levels such as the African Union (AU), the United Nations (UN) through MONUSCO, the governments of the DRC, Rwanda, Uganda and to some extent Burundi, the European Union (EU) and the United States to mitigate the impact of the conflict (see Rugeje \& Maeresera, 2016). Despite efforts by these actors at resolving the conflict and building peace in eastern Congo, there have not been much pronounced or all-out efforts by the Southern African Development Community (SADC). This is despite the fact that eastern Congo falls in the sub-regional body's area of responsibility in as far as conflict resolution and peacebuilding is concerned. This article analyses the constraints and prospects of SADC's capacity to intervene in eastern DRC in order to resolve the recurring conflict as well as building peace. The analysis is divided into five sections. The first section contextualises conflict resolution and peacebuilding as it relates to the recurrence of the eastern Congo conflict.The second section provides an overview of the conflict by tracing its recurrences with particular emphasis on the political, economic and military/security dynamics of the conflict as well as the various actors involved particularly in this recurrence. The third section briefly discusses the efforts that have been made by various actors at sub-regional, regional and international levels in trying to resolve the conflict and build peace. In the context of the above efforts, the fourth section makes a projection of the complementary initiatives that SADC can take in terms of sustainably resolving the conflict and building peace. In line with the current state of affairs in the Congo in general and the eastern part of the country in particular, the fourth section looks at the constraints and prospects that the sub-region will likely encounter in its quest towards sustainable conflict resolution and peace building in eastern Congo. Given the current scenario, policy suggestions are proffered with regard to what approach or strategy the sub-regional body can adopt in pursuit of resolving the recurrence of conflict and build sustainable peace in the DRC. Conclusions are drawn in the last section.

\section{Conflict Resolution And Peace Building In Brief Context}

Being a pluralistic field, conflict resolution takes various theoretical orientations and these depend on the specific practice contexts and objectives (Hansen, 2008). Thus, any conflict resolution mechanism to be adopted in the context of the recurring conflict in eastern Congo has to be theoretically and practically adopted with specific reference to its contexts and objectives. Gil (1998) makes an important observation to the effect that conflict 
resolution calls for the formulation of both short-term and long-term strategies by conflict resolution practitioners with the aim of promoting and enhancing communications between the oppressed and their oppressors as well as facilitating discussions among oppressed individuals to help them determine their needs and their preferred means to meet them. In the context of this article, any initiative by SADC to resolve the recurring conflict in eastern DRC would be analysed, regardless of whether the sub-regional body would consider the above theoretical basis of conflict resolution or it would put these theoretical prescriptions into practice.

Peace building can be understood in two ways, namely narrowly and broadly. A narrow definition of peace building focuses on the phase when conflict has just ended; this phase is known as post-conflict peace building. It refers to numerous forms of activities aimed at achieving peace including capacity building, reconciliation and the transformation of society, with specific emphasis on repairing broken human relationships (Sentama, 2009). A broader definition of peace building, on the other hand, would look at shorter- term issues such as peacemaking and peacekeeping over and above long-term endeavors towards conflict transformation. In this regard Sentama (2009, p. 24) asserts that, "in this encompassing and broad view, peace building includes early warning and response efforts, violence prevention, advocacy work, civilian and military peacekeeping, military intervention, humanitarian assistance, ceasefire agreements, normalization and reconciliation." This renders peacebuilding as involving prevention, peacemaking, peacekeeping and peace reconciliation (Sentama, 2009).

De Coning and De Cavalho (2013, p. 11) define peace building as a highly complex process comprised of a host of actors undertaking various tasks with the sole aim of transforming a system of conflict in order to eradicate the roots of the conflict and develop a solid ground for lasting and just peace. The two authors warn that the more peace building activities, projects and programmes are conducted without a coordinated or coherent approach being in place, the more competition, duplication and unnecessary overlap will result. This will often lead to confusion, rivalry for resources and may even create causes for conflict rather than reducing these (De Coning and De Cavalho (2013, p. 11). The article will therefore, discuss the constraints and prospects of SADC's capacity to resolve the recurring conflict and sustainably build peace using a coordinated and coherent approach as suggested by De Coning and De Cavalho.

In analysing SADC's intervention capacity in resolving the conflict and building peace in eastern DRC, this article takes into consideration whether or not the sub-regional body has been able or will be able to consider key factors in as far as peace building is concerned. These include among others: early warning, response efforts, violence prevention, advocacy work, civilian and military peacekeeping, military intervention, humanitarian assistance, ceasefire agreements, normalisation and reconciliation.Taking into consideration the current efforts by MONUSCO, in working along with the Intervention Brigade, the article 
will evaluate other important factors such as the need for SADC to take a coordinated and coherent approach that does not result in unnecessary duplication of peace building efforts, thereby creating conflicts among various actors. Such an approach will possibly result in the attainment of sustainable peace in eastern Congo. It is now important to take a brief overview of the recurrence of conflict in eastern DRC as part of the effort in analysing the sub-regional body's capacity to sustainably resolve the conflict and build peace.

\section{An Overview of Conflict Recurrence in Eastern Congo}

The successful hosting of the Inter-Congolese Dialogue (ICD) by the South African government with the sub-regional, regional and international support of SADC, the AU, the UN and other relevant key players heralded an optimism in as far as the search for a sustainable solution to the conflict in DRC was concerned. Despite DRC having taken most of the key steps recommended as measures for a state recovering from conflict, the country has not experienced durable peace. Armed conflict has continued to recur in the Congo and this conflict has been emanating specifically from the eastern part of the country. The recurrence of conflict in eastern Congo has been generally centred on the armed activities of various militias or armed groups operating in the North and South Kivu provinces. These militias have been engaged in various activities such as armed attacks on the Congolese Armed Forces (FARC) units deployed in eastern Congo, the international peacekeepers, as well as the forced recruitment of child soldiers, the raping of vulnerable young girls and women, and looting from the generality of the Congolese civilians. Innocent civilians who resisted the demands of rebel combatants suffered mass executions as well as conscription into the rebels' political and military ranks, coerced political and financial support, and forced marriages.

There have been many questions raised regarding the formation of political and military structures as well as about the financial and logistical support of armed groups operating in eastern Congo.Three major players at the centre stage of the political and military dynamics of these rebel militias have been the government of DRC itself and the governments of Rwanda and Uganda (Perera \& Beswick, 2013). The Congolese government has been blamed by the governments of Rwanda and Uganda for not being able to keep eastern Congo under its security control (Dizolele, 2004). Kinshasa's security inability, in the views of Kigali and Kampala, has been a key causal factor that has enabled those armed rebel militias, notably the Forces of the Democratic Liberation of Rwanda (Interahamwe) and the Lord's Resistance Army, to create rear bases in North and South Kivu respectively (Dizolele, 2004). In the views of the governments of Rwanda and Uganda, eastern Congo and specifically the North and South Kivus have been used as launching pads for military attacks on Uganda and Rwanda.

Whilst that has been the case in the views of Kigali and Kampala, the Kinshasa government, on the other hand, has been blaming the governments of Rwanda and Uganda for the political formation and military structuring of rebel militias fighting against the Congolese 
government. ${ }^{1}$ These militia groups include the National Congress for the Defence of the Congolese and the M23. These two major groups have been launching military attacks against the Congolese government troops. Before counter-offensive operations by the International Monitoring Force which led to their withdrawal from mainly Uganda and to some extent Rwanda, these rebel groups had reportedly been carrying out various acts of sabotage, mass killings and torture of innocent civilians, rape, and forced recruitment of child soldiers, among others. Most of these rebel groups' successful military operations prior to the deployment of the International Monitoring Force were dependent on the alleged provision of political support and military logistical and technical sustenance from Rwanda. The above political dynamics and military developments in eastern Congo have had devastating effects on the Congolese civilian population and have continued to incapacitate the Congolese government from guaranteeing the security of its nationals in that part of the country. Whilst eastern Congo has continued to experience an unstable security situation, diplomatic political and military efforts have been made at various levels to try and resolve the conflict. It is important to briefly discuss these efforts and the generality of the actors involved.

\section{Tracing the Various Efforts at Resolving the Eastern Congo Conflict}

The recurring conflict in the Congo has seen various actors at various levels - bilateral (DRC-Rwanda, DRC-Uganda), regional (the East African Community (EAC), through ICGLR, SADC) and international (the AU and the international community) - making efforts to resolve the conflict. Whilst the main thrust of this paper is the critical analysis of the prospects and constraints of SADC's capacity to resolve the conflict and build sustainable peace, it is equally prudent to make a brief analysis of those initiatives made by other actors outside SADC.

Political efforts at the bilateral level were undertaken by the Congolese government with its respective key neighbouring countries who have immediate national security interests in as far as the conflict in eastern Congo is concerned. There have been Joint Permanent Commissions (JPCs) on Politics, Defence and Security either between the governments of DRC and Rwanda or between DRC and the Uganda government. Joint Permanent Commissions on Politics, Defence and Security at tripartite levels, that is, among the three key countries (DRC, Rwanda and Uganda), were also formed.There have been deliberations among the three countries at the respective levels of the Presidency, Foreign Affairs, and Defence and Security ministries. All these initiatives were meant to find a solution to the conflict.

The military efforts at bilateral levels included joint military operations either between the government forces of DRC and Rwanda or the forces of DRC and Uganda. Tripartite joint 
military operations were carried out by the armies of the three countries. All the military operational efforts were meant to prevent escalation of the recurring conflict through carrying out counter-offensive operations against rebel groups operating and destabilising eastern Congo either against the Congolese government or the government of Rwanda or Uganda. The notable joint military initiative was the one carried out by the governments of DRC and Rwanda named 'Umoja Wetu'.Operation 'Umoja Wetu' was meant to deal with the threat posed by both the FDLR against Kigali and the CNDP against Kinshasa (see International Crisis Group, 2009, pp. 3-11).

In one analyst's view, the agreement seems to have been necessitated by the considerations of the political and military opportunity costs of the two governments. ${ }^{2}$ In the case of Rwanda, there seems to have been pressure on Kagame to do something about the likely international political repercussions of the alleged support for CNDP. International political pressure mounted on the government of Rwanda, with the notable withdrawal of financial aid by countries such as Sweden and Netherlands. ${ }^{3}$ On the other hand, the Kinshasa government seems to have taken the agreement as an opportunity to sustainably deal with the military threat posed by the CDNP which had significantly affected the capacity of the Congolese military to stand and fight as well as defend Congolese innocent civilians against hostile enemy forces in that part of the country. ${ }^{4}$

Whilst the military offensive (which was carried out without the support of MONUC, AU, EAC and to some extent SADC) was meant to reduce the escalation of armed hostilities in eastern Congo, there was not much success in the accomplishment of the joint mission by the DRC and Rwandan government forces together with the CNDP. ${ }^{5}$ The operation also reportedly resulted in the massive forcible recruitment of child soldiers into the FDLR, raping and looting - among other human security related threats in eastern DRC. One political and security analyst questioned the genuineness and sustainability of that DRC-Rwanda bilateral cooperation in addressing the security situation in eastern Congo, specifically through operation 'Umoja Wetu'. ${ }^{6}$ The analyst had suspicions of the capture of Laurent Nkunda by the Rwandan Defence Forces, as well as the disarming of the rebel troops loyal to the Tutsi General. ${ }^{7}$ There were also questions as to how the two countries' bilateral military cooperation would continue to hold after that joint operation. The joint operation did not achieve much with regard to the aims or objectives of the mission. Whilst the governments of the DRC and Rwanda claimed that operation 'Umoja Wetu'had some relative success in reducing the operational capacity of the FDLR, there have been reported military activities by the armed rebel troops in eastern Congo against the Congolese civilian population in that part of the Congo (see International Crisis Group, 2009, pp. 3-11). Despite the fact that a few of their members either deserted or were disarmed and demobilised under MONUC's DDRRR program, the FDLR's military capacity seems to be boosted by the support they continued to receive from some armed MayiMayi elements in the Kivus who were opposed to any political or military cooperation between the governments of Rwanda and the DRC as well as between the governments and MONUSCO (International Crisis Group, 2009, p. 13). 
The presence of the FDLR in eastern Congo continued to pose a national security threat in the view of the Kigali government. The presence of the FDLR in the east also put the Congolese government in a predicament whereby Kinshasa was not capable of protecting and preventing massive human rights violations by militia groups against its citizens, or of defending the territorial integrity of its borders against foreign troops such as the Rwanda Defence Forces (RDF) if they were to redeploy and support any given militia group that may come even after the former M23 militias were reintegrated into the Congolese forces' rank and file. Kinshasa could also not protect the illegal exploitation of the strategic mineral resources by the armed militia, particularly the FDLR (International Crisis Group, 2009, p. 16).

Despite the reduction of the M23 armed threat in eastern Congo, and the reported withdrawal of Rwandese troops from the DRC, the possibility of a recurring full-scale armed conflict cannot be ruled out in the current scenario. The continued armed activities of the FDLR may leave Kigali with no option but to reconsider its covert and overt military involvement in the east in pursuit of preventing FDLR from launching military offensives into Rwanda from eastern DRC. Rwanda continues to blame the Congolese government of lacking the political will and capacity to deal with the FDLR (International Crisis Group, 2009, p.18). These accusations continue to be levelled against the Congolese government by Rwanda despite the fact the former seems not to have any control or offer any support to the FDLR.In the context of the above scenario, the security situation in eastern Congo remains relatively complex and unstable.

At the level of the East African Community, political efforts to resolve the eastern Congo conflict have been generally focusing on facilitating and promoting political dialogue. The EAC, through the International Conference on the Great Lakes Region (ICGLR) has been making diplomatic initiatives to try and bring the belligerents to the negotiating table. ${ }^{8}$ The ICGLR has been playing a pivotal role in also trying to bring together state and non-state actors with a view to resolving the conflict the eastern Congo. There has not been much progress though in these efforts. The same goes for efforts at the African Union level. Recurring conflicts in eastern DRC have been on the agenda of AU Heads of State Summits and the Peace and Security meetings. Special AU envoys, notably the former Nigerian President Olusegun Obasanjo, were once appointed with the objective of trying to bring the belligerents involved in the conflict to the negotiating table (Feeley \& Thomas-Jensen, 2008).

At the level of the international community in general, and the UN in particular, various diplomatic and political initiatives have been made with regard to resolving the conflict (Rugeje \& Maeresera, 2016). Sanctions have been imposed on the political and military hierarchy of the rebel militia groups operating in eastern DRC (Matsiko, 2013). International warrants of arrests have been issued by the International Criminal Court (ICC) to the top military leadership of these rebel groups for crimes against humanity. ${ }^{9}$ On a related note, the international community also made efforts through a UN-appointed panel of experts which investigated and released a report which implicated Rwanda and Uganda as being 
responsible for providing political and military support to the respective armed rebel groups fighting against the Congolese government forces in the east. ${ }^{10}$ The findings of the report were, however, dismissed as allegations by the governments of Rwanda and Uganda.

In addition to the diplomatic and political efforts at the international level through the $\mathrm{UN}$, international military efforts in resolving the conflict in the east revolved around the activities of MONUSCO. From the time of its initial deployment up to the present, MONUSCO has made some military efforts meant to stabilise the security situation in the Congo in general and recurring conflict in the east in particular (Menodji, 2013). The UN mission in Congo has tried its best to facilitate dialogue among the conflicting parties in line with its mandate. There has been little tangible success though (Dizolele, 2004). At one time the Congolese government called for the withdrawal of the UN peacekeeping forces and the ending of the Mission in Congo. Such an eventuality shows the political challenges faced by the international community at the level of the UN in as far as efforts at resolving the conflict in eastern DRC are concerned.

On the same note, it is prudent to note that during the initial stages of MONUC's deployment in the DRC there was reportedly less cooperation between the UN Mission and the Congolese government particularly in relation to MONUC's attempts at disarmament (Menodji, 2013). The Congolese government was accused of not being fully supportive of the UN body's DDRR program. ${ }^{11}$ Instead, the Congolese government worked hand in glove with both the FDLR and the MayiMayi to bolster their strength and capacity in trying to effectively deal with military threats in eastern Congo. ${ }^{12}$ This was despite of the fact that the Kinshasa government was well aware of the fact that one of MONUSCO's tasks was that of implementing the DDRRR when the UN troops were deployed in 2002. ${ }^{13}$

However, recent events show how MONUSCO, alongside troops from the Force Intervention Brigade (FIB) together with Congolese armed forces, successfully launched military offensives which resulted in the withdrawal and surrender of M23 rebels. However, after subtracting these relative successes, the situation in eastern Congo remains complex and prone to the recurrence of a full-scale armed conflict. Whilst the mandate of MONUSCO has been extended, the UN mission continues to face political and military challenges. The insecurity situation in the east may continue to be caused by armed activities of the FDLR and other militia such as the MayiMayi. Such activities may include human rights abuses, summary executions, sexual and gender-based violence, large-scale recruitment of children, and attack of Tutsi civilians in the DRC. In addition to the above insecurities, neutralisation of these armed groups, particularly the FDLR, remains a challenge. If these groups refuse to voluntarily disarm and demobilise, how feasible will be it be to undertake forcible disarmament of these armed militia? Being a member of the FIB and part of SADC and ICGLR, the Tanzanian government's suggestion to have Rwanda and Uganda negotiate with the respective armed groups that launched attacks from the DRC into their countries was outrightly rejected by both Kigali and Kampala. ${ }^{14}$ In the context of the above, and taking into consideration that MONUSCO alongside the FIB were mandated by the UN Security Council to support the Kinshasa government to address the security situation in the 
country, particularly in the east, where then would SADC fit in? What diplomatic/political and military security initiatives can the sub-regional body take to complement the current efforts of the role players concerned? What will be the likely constraints (in the context of regional dynamics between countries and leaders) that undermine SADC's efficacy in intervention efforts? What are the prospects that such efforts will enhance SADC's capacity to take control of these dynamics?

\section{SADC's Capacity at Resolving the Conflict and Building Sustainable Peace}

SADC's capacity for resolving the conflict in eastern Congo and for building sustainable peace can be evaluated through the region's political, diplomatic and military security

efforts. At the SADC political and diplomatic level, the recurring conflict in eastern Congo has always been among the key items on the agendas of most SADC Summits - featuring Heads of State and Government. However, no success has been achieved by the relevant SADC in resolving the recurring conflict in the east and building sustainable peace. One example of such failure is that of the SADC Strategic Indicative Plan of the Organ (SIPO). There were high hopes for SADC's conflict resolution and peace building capacity following the revision of SIPO's modus operandi in Dar es Salaam in November 2012. Having been launched in 2004 in Dar es Salaam, Tanzania, the aim of revising the SIPO was to effectively coordinate peace and security issues affecting the sub-region (Zambara, 2013). This coordination was done through the Organ on Politics, Defence and Security Committee (OPDSC). There were expectations that the political and diplomatic efforts at resolving the conflict in eastern Congo would be successful. On a related note, the revision of SIPO was followed by a SADC extraordinary summit of the heads of state and governments whose focus was to map the way forward to resolving conflicts in the sub-region and in this case, eastern Congo. ${ }^{15}$

It was at this summit that SADC countries pledged to deploy the Standby Force, referred to as a neutral force, in order to counter military offensives by the various armed rebel groups in eastern Congo, most notably the M23. This particular sub-regional military effort was accomplished through the efforts of the then SADC Chair of the Organ (Tanzania's President Jakaya Kikwete). ${ }^{16}$ Whilst such military efforts were made by SADC, it was important to note the remarks made at the same SADC summit by the President of Uganda, Yoweri Museveni, on the need for the SADC sub-region to be cautious when dealing with the eastern Congo conflict (Zambara 2013). In the view of the Ugandan President, any efforts by SADC to resolve the eastern Congo conflict and achieve sustainable peace should take two critical issues into consideration: firstly, that the conflict and instability in the Congo affects the Congolese people and neighbouring countries, and secondly, that the same conflict and instability is strictly internal. ${ }^{17}$

From the above, it would be relatively fair to note that concerning any SADC political and diplomatic initiative in resolving the conflict in eastern Congo there have been doubts about whether the political and security dynamics of the conflict have been taken into consideration. 
SADC seems not to have been on the political and diplomatic level of thorough analysis and proper follow-up work with regard to eastern Congo's recurring conflict. There seems to have been less political and diplomatic zeal at the political and diplomatic level of the SADC sub-region. The sub-region shows less diplomatic and political urgency and coherence on the need to resolve the conflict. One Great Lakes regional political and security analyst notes that the SADC political/diplomatic oomph in the eastern Congo conflict seems to be affected by many significant factors. These include, among others, relative hesitancy in terms of the 'perennial' lack of political will and divergent national interests among the member states, and bilateral relations between individual member states and those outside the sub-region. ${ }^{18}$. There seems to be 'an unpronounced historical divide' among SADC member states that can be traced to the different intervention approaches which later resulted in the region having 'pacifist' and 'militarist' camps (Baker \& Maeresera, 2009, pp. 109110; Ngoma, 2004). This regional divide in the context of the lack of political will, which at times can translate itself into 'divided political will', has often resulted in SADC having a section of some member states opting for military actions, others preferring more peaceful and diplomatic initiatives, whilst others do not opt for any specific position. This third or last section of the group of SADC member states would instead opt to remain outside the problem whilst they publicly show zeal and will to solve the problem that the region would be facing (Baker \& Maeresera 2009, p. 109; Ngoma, 2004). The conflict seems to be of less significance to the bulk of members of the sub-region in terms of the effects it has on their respective national interests. ${ }^{19}$ In terms of the above scenario of 'three SADCs', there is arguably less significant diplomatic and political unity of effort in terms of the member countries' support for the current peace endeavours following the deployment of troops from member countries (South Africa, Tanzania and Malawi) as part of the Intervention Brigade.

The political and diplomatic efforts by SADC also seem to be affected by the fact that there is currently no tangible and sustainable peace plan adopted by the sub-region specifically on the Congo conflict. SADC has also not been able to take the initiative to engage key role players into the conflict. The sub-regional body has been reluctant to take advantage of the peace, security and cooperation framework which guides MONUSCO's modus operandi in the DRC following the one year extension of its mandate. ${ }^{20}$ With the exception of the invitation and participation of Uganda in the November 2012 extraordinary summit in Tanzania, SADC has done little to take aboard non-SADC state and non-state actors who are, however, key stakeholders to the recurring conflict in eastern Congo. There have not been tangible follow-up extraordinary summits specifically on conflict in eastern Congo held with that zeal and urgency at the SADC level. There also seems to have been little, if any, political/diplomatic initiative to include key stake-holders in as far as resolving the conflict is concerned. Whilst the recurring conflict in eastern Congo falls within the SADC sub-regional area of responsibility, it should also be noted that the same conflict has direct security implications for the whole Great Lakes sub-region. Hence the need for a political and diplomatic offensive synchronised and coordinated by SADC with the continued assistance of the ICGLR, AU and the UN. Whilst the above discussion centred on the constraints faced by SADC with regard to its political and diplomatic capacity in resolving the conflict, it is 
also equally important to make a brief critical analysis on the military security dimension of the sub-region's efforts made and the capacity it has in resolving the same conflict.

SADC's military security efforts can be analysed in line with the sub-region's cooperation with MONUSCO. It should be realised that with the exception of South Africa, Malawi, Tanzania and Zambia, the rest of the SADC countries did not contribute troops to the UN Intervention Brigade that was deployed in eastern Congo. Despite the fact that the conflict in the east falls in the sub-regional body's area of responsibility for conflict resolution and peace building, SADC was either excluded from regional and international political initiatives and efforts in resolving the Congo conflict or the body had little or no political will to forcibly take initiatives to engage and cooperate with other role players in conflict resolution and peace building efforts. A notable example is that when MONUC was deployed in the Congo, save for a contingent of the South African Defence Forces' peacekeeping troops which provided specialised technical support to the MONUC Headquarters in Kinshasa, the SADC regional body played little or no supportive complementary role to MONUC's efforts. ${ }^{21}$ One conflict resolution and peace building analyst argues that the less involvement or non-involvement of SADC in the conflict resolution and peace building efforts in the DRC, particularly in the recurring conflict in the eastern DRC, can be attributed to the 'do-it-alone' attitude of MONUC in the initial stages of the UN Mission in the Congo. ${ }^{22}$ However, it also cannot be ruled out that the sub-regional body lacked the initiative to lobby for critical coordination and cooperation with MONUC. This was despite the troop contribution to MONUC by four SADC member states, namely South Africa, Malawi, Tanzania and Zambia. It would also appear that the efforts at DDRRR were left to the Congolese government, MONUC, the AU and other members of the international community. It is yet to be seen whether SADC would take advantage of the presence of troops from South Africa, Tanzania and Malawi (who are part of MONUSCO's FIB) to complement respective peace roles as given scenarios or as situations demand.

Expectations were high following the pledge by SADC at the November 2012 extraordinary summit to deploy a force in the east. However, the SADC initiatives to deploy the regional force could have been to some extent affected by international political dynamics of the conflict in eastern Congo. It cannot be ruled out that there were sub-regional expectations that the force which was to be deployed in eastern Congo would wholly be a SADC Standby Force, composed of troops from all the SADC member countries in line with the agreed upon SADC Standby Force concept of operations. However, at the time of writing this article, the situation on the ground has become different. As already noted, from among all SADC member states, it has only been South Africa (which contributed a battalion), Malawi (which also contributed a battalion, together with a platoon of special forces) and Tanzania (which contributed a battalion and the Force Commander) that are part of the force which was deployed to the east (Phiri, 2013; see also Radebe, 2013).

The development of the above scenario could be attributed to (as indicated earlier on) the lack of commonality of national interests, lack of political will, and to relative hesitancy to peace commitment among the SADC member states (Nathan, 2004). If SADC member 
countries had taken the deployment of the Standby Force as a matter of urgency in the same manner as when they contributed troops to take part in the SADC peacekeeping Field Training Exercises (FTXs), perhaps the sub-regional body could have deployed a Standby Force as a unified entity to counter armed rebel military offensives in the east for the protection of civilians. A rapid deployment of the Force could have been effected whilst political and diplomatic solutions to resolve the conflict were sought and sustainable peace building measures were undertaken. If the sub-region had showed unity of purpose in speedily deploying the SADC Standby Force as a unified force with all member countries taking part, it cannot be ruled out that perhaps the international community would have been convinced and would have supported the sub-regional force instead of having a scenario where there was a 'Neutral International Force' with only few SADC member states contributing 'token' troops to the Force. This may be said despite the relative progress made by the 'Neutral International Force'. It therefore, seems as if a lack of political will, divergent national interests, lack of commonality of purpose in terms of sub-regional peace have been the key factors that have so weakened SADC's sustainable conflict resolution and peace building capacity in as far as recurring conflict in the eastern Congo was concerned.

\section{Whither SADC Capacity In Eastern Congo Conflict?}

Having discussed SADC's conflict resolution and peace building capacity and the challenges it has faced in trying to resolve the conflict and build sustainable peace in eastern Congo, it is equally important to proffer suggestions on what SADC can do to effectively enhance its capacity to resolve the recurring conflict and build sustainable peace in the DRC in general and eastern Congo in particular.

\section{Strengthening Sub-Regional Coherence and Political Will among Member States}

It is suggested that the SADC member states take an urgent common political approach to resolving the conflict rather than wait for routine SADC summits where the recurring conflict is only one of several items on the agenda. Whilst member states have different national interests, the respective SADC political structures and particularly the 'Troika' must committedly push for the commonality of interests among member states in the context of promoting sub-regional peace, security and stability for the development of the region. Sub-regional commitment to the resolving of the recurring eastern Congo conflict and the building of sustainable peace must be treated and promoted by the relevant SADC political structures as a common interest among member states. Whilst the convergence of interests on core issues appear very difficult to realistically attain, from the authors' view point, SADC member states must work towards common peace and security goals with other important actors involved in the conflict such as ICGLR, AU and the UN. 


\section{Early Warning and Timely Effective Action}

The conflict in eastern Congo has been recurring with devastating effects on the Congolese civilians. There is still hope that the overall objective of the SADC Early Warning Centre, which is 'to strengthen the SADC mechanisms for conflict prevention, management and resolution in line with the provisions of the Protocol on Politics, Defence and Security Cooperation and Strategic Indicative Plan for the Organ' (Southern African Development Community, 2012), will be effectively attained. It should be noted that the main functions of the SADC Early Warning Centre are: to 'compile strategic assessment and analysis of data collected at regional level; share information on major issues posing threat to the security and stability of the region; and propose ways and means for preventing, combating and managing such threats' (Southern African Development Community, 2012). Thus, whilst the SADC Early Warning Centre can execute its primary functions with specific reference to conflict in eastern Congo, there is need for timely and effective early action by the relevant SADC political institutions in as far as strengthening the mechanisms for conflict prevention, management and resolution. Early warning and timely effective action will possibly enhance SADC's capacity at resolving conflict recurrence and building sustainable peace in the DRC, specifically in eastern Congo.

\section{Building Blocks of Sharing Responsibility on Conflict Resolution and Sustainable Peace Building}

Whilst conflict in eastern Congo falls within SADC's area of sub-regional responsibility, the fact that the conflict has immediate security effects on the entire Great Lakes region and spill-over strategic effects on Africa and beyond means that there is a need for SADC to come up with a workable plan for a coordinated synergy at diplomatic, political and military/security level with other role players. Firstly, SADC should consider working closely at diplomatic and political levels with the ICGLR in most, if not all, future political and diplomatic initiatives (guided by the precedence of the two SADC/ICGLR summits held in Namibia and South Africa at the end of 2013). The invitation and participation of Uganda in the November 2012 SADC extraordinary summit should have set precedence and tone for SADC to take aboard other state and non-state actors outside SADC, mostly ICGLR's active member states such as Burundi, Rwanda and Uganda that have immediate political and security interests in all future diplomatic and political manoeuvres of resolving the recurring conflict. In addition to the ICGLR, there is also need for SADC to take the lead in harnessing vital diplomatic and political support and cooperation from the AU, the $\mathrm{UN}$ and the international community at large. The same applies to non-state actors at SADC and beyond (Paffenholz \& Spurk, 2006). It is equally possible that the involvement of these non-state actors will go a long way to enhance the sub-region's capacity for resolving the eastern Congo conflict and building sustainable peace. On a related note, SADC should also take the initiative to promote research through regional think-tanks whose special focus is 
on conflict resolution and peace building. Such research initiatives would specifically focus on the recurring conflict in the eastern Congo. This would enhance and add to SADC's policy guidelines for the effective resolution of the conflict and the building of sustainable peace.

On the military and security level, SADC institutions should also consider close cooperation and coordination with military/security institutions from the above-discussed relevant state and non-state actors.The Organ on Politics, Defence and Security Committee (OPDSC) may consider drafting an effective and workable framework where SADC military/security institutions coordinate and synergise with those of the ICGLR, AU, UN and the international community. Genuine considerations must be made by all SADC member states in their commitment to the operational functioning of the Standby Force. SADC member states must effectively contribute troops to the Standby Force's deployment to eastern Congo in the same way they do in joint Field Training Exercises. Token contributions must be avoided. Even when genuine contributions are made in full strength to the SADC Standby Force's operational deployment capability in eastern Congo, there is also need for the Force to work with both state and non-state actors in the region and beyond in the grand mission of creating a conducive environment for the resolution of recurring conflict and the attainment of sustainable peace.

It is evident that the more challenging tasks of brokering national reconciliation, demobilising and disarming the DRC's many militia, and reviving local and national government were left to the UN operation in the DRC, otherwise known by its moniker MONUSCO. The lessons of MONUSCO's attempts at peace building and reconciliation are well known and need not be repeated here. Perhaps, the challenges or the failure of MONUSCO has led to a strong SADC reluctance to engage effectively in peace building in the eastern part of the DRC. But in the haste to write MONUSCO's eulogy in the DRC, observers should not overlook a potential intervention by SADC that can have a positive impact on peace building.

\section{Dealing with Spoilers}

The eastern DRC conflict is of broader interest for one key reason. The eastern DRC conflict helps to refine scholars' understanding of the nature and complexity of spoilers in protracted crises. In eastern DRC there is a wide range of spoilers that exist and must be accounted for in efforts to manage them. In essence, spoilers are a serious challenge to state building efforts in the DRC. These actors view a revived role of the central state or any return to law and order as a threat to their political and economic interests. Notably, most analyses of the spoiler problem, such as Stephen Stedman's seminal work (1997), focus on groups and individuals seeking to undermine peace processes or prevent the implementation of peace accords. This is entirely appropriate, as spoilers devote most of their efforts to blocking reconciliation and perpetuating conditions of conflict. In essence, spoilers are 
a serious challenge to state building efforts in the DRC. Unsurprisingly, peace building efforts encounter resistance from groups and individuals who perceive that their economic and political interests are threatened by a return of a functional governance system in eastern DRC. SADC must play a role because some of these spoilers are external such as Rwanda and Uganda. Meanwhile, local spoilers include militia, factions, warlords, or leaders who believe peace building poses a fundamental threat to their political or economic interests. For spoilers, especially warlords feel the return of the rule of law could result in their marginalisation or even arrest for war crimes. For business people who have benefited from the conflict in eastern Congo, the return of normalcy may carry too many risks of high taxes, corruption, expropriation and so forth. Furthermore, much is at stake over who controls natural resources. Among ethnic groups and other social groups, there is fear that the return of the central government will result in the control of resources in the east by a narrow coalition of ethnic groups that will use the state as an instrument of domination at their expense. Likewise, militia controlling income-generating resources may be unwilling to see those revenues redistributed to other regions, or even to cede control over revenues to a national government based in Kinshasa. As such, these militia may continue to fight to maintain control over what they perceive to be their asset. In a way, although the potential rewards of state revival are high, so too are the risks.

\section{Focusing on State Building}

It is a truism that state failure is ultimately at the root of many of the security threats and crises of development in Africa. It follows then, that any long-term strategy intended to address security concerns in the eastern part of the DRC must focus first on state building. Yet several general challenges confront efforts to revive a central government in the DRC. The legacy of the 1998-2003 period of civil war in the DRC is profound. It includes unaddressed war crimes and deep inter-ethnic grievances over atrocities committed in neighbouring Rwanda as well as reprisals in eastern DRC; occupied territory, the rise of warlords and others with vested interests in continued lawlessness and impunity, the near-universal spread of armament, massive internal displacement, and unresolved secessionist postures in the east. Addressing these challenges is a mammoth task. Rebuilding the DRC must proceed from rubble. Furthermore, the state in the DRC has a history for producing conflict. In actual fact, the repressive and predatory character of the DRC state especially under Joseph Mobutu has left a legacy of deep distrust among the Congolese toward the state as an institution. The state has been the primary source not only of power but of wealth - as the catchment point of aid, the point of control of government tenders and state-owned enterprises, and as the coercive instrument which empowered ethnic groups have used to expropriate the assets of rivals. In other words, the repressive Mobutu regime fuelled sharp resentment and fear toward the state itself in the Congolese public. The subsequent freezing of that aid by Western countries in the late 1980s and 1990s led to the rapid decline of the state. In essence, Mobutu's Zaire was a castle built on sand. Although complete state collapse was not unavoidable in the post-Cold War era, a general condition of state failure was. By the 
mid-1990s the then Zaire (DRC) was already a failed state. Fierce government repression, heightened ethnic cleavages and animosities, and gross levels of corruption all combined to accelerate the state's decline. With this in mind, SADC should assist efforts targeting state building in the DRC to demystify the predatory nature of the state particularly the central government. Certainly state-building measures may arrest deep inter-ethnic animosities and distrust that are partially responsible for the failure of ethnic groups especially in the eastern part of the country to unite in the post-Mobutu era. Some of the measures may include the pouring in of money as well as mobilising massive investments into the country (possibly from international partners) that may stimulate and strengthen legitimate business. In the long run such measures may help to reshape local interests in security and rule of law, and eventually local power relations.

\section{Conclusion}

In the age of globalisation, regionalism and the technological revolution, national governments in conflict-ladden states can no longer insulate their internal problems from external scrutiny (Bajunid, 2009). It is no wonder then that the recurrence of conflict in the DRC has attracted international attention. As can be seen, since 1998 eastern DRC has been in a conflict mode, making it one of the longest-running instances of conflict in the postcold war era. This track record has earned eastern DRC the dubious distinction of being one the world's foremost burial ground of externally-sponsored peace building initiatives. The DRC is not, however, merely a repository of lessons learned on how not to pursue peace keeping and peace building. In some respects, it is at the forefront of a poorly understood trend- the reluctance of regional bodies to prevent recurrence of conflicts. But the repeated failure of efforts by the UN to effectively build peace in eastern DRC must not obscure the potential success of the SADC regional peace-building efforts or initiatives. The article presented a critical analysis on the prospects and constraints of SADC's capacity to resolve conflict and build sustainable peace in the context of conflict recurrence in eastern Congo. The concepts of peacebuilding and conflict resolution were discussed with reference to this conflict, where it was noted that the inclusion of all role players was the key in conflict resolution and peace building. A brief overview of the recurring conflict was outlined; the various actors involved in the recurring conflict as well as their interests were discussed and analysed. Diplomatic, political and military efforts that have been made at bilateral levels, that is, between the DRC and relevant state actors, the Great Lakes, the AU, UN (MONUC) and the international community were critically analysed. The challenges that have been encountered at all these levels and the capacity of SADC to resolve the recurring conflict were discussed. It was noted that there have been diplomatic, political and military security efforts by SADC through the utilisation of the sub-regional body's relevant institutions in trying to resolve the conflict. However, the challenges encountered in all SADC efforts revolve around issues such as non-coherence, lack of political will and zeal, divergent national interests among member states, the non-commitment to urgently deal 
with the conflict as a common sub-regional interest, among others. It was also discussed that SADC has not been able to include other actors at state and non-state levels in its diplomatic, political, military, and security quest to resolve the conflict and build peace in the context of the recurring conflict. Basically all these efforts have militated against the sub-regional body's conflict resolution and peace building capacity. Recommendations were proffered on how SADC may be able to use its capacity to deal with the recurring conflict in eastern Congo in terms of resolution and sustainable peace building. These include the strengthening of coherence, political will and energy among the member states in order to take the recurring eastern Congo conflict as a common sub-regional interest that needs to be urgently resolved. It was also suggested that the SADC Early Warning system must be supplemented with a mechanism capable of timeous and effective response from the relevant SADC political institutions. There is also need for SADC to consider building blocs of responsibility, sharing and effective coordination with state and non-state actors outside SADC for the sake of resolving the conflict and building peace in eastern Congo.

\section{References}

Allen, T., M. (2011). United Nations led disarmament, demobilisation and reintegration $(D D R)$ in the Eastern Democratic Republic of Congo (Unpublished master's thesis Security Studies, Naval Post-Graduate School), California.

Bajunid, O. F. (2009). The conflict in Thailand's deep south and its international implications, Journal of International Studies, 5, 40-57.

Baker, D.-P., \& Sadiki, M. (2009). SADCBRIG intervention in SADC member states: Reasons to doubt. Africa Security Review, 18(1), 106-110.

Boras, A. H.. (2009). The International Conference on the Great Lakes Region (ICGLR) review of Norwegian support to the ICGLR Secretariat, Norad. Retrieved from <http:// www.norad.no/en/tools-and-publications/publications/publication?key=131851

De Coning, Cedric H., \& Gustavo de Carvalho. (2013). ACCORD Peacebuilding handbook. ( $1^{\text {st }}$ ed). Umhlanga Rocks, ACCORD. Retrieved from http://www.nupi. no/Publikasjoner/Boeker-Rapporter/2013/ACCORD-Peacebuilding-Handbook

Dizolele, M., P.. (2004). The UN in Congo: The failure of a peacekeeping mission. 10 May. Retrieved from http://www.worldsecuritynetwork.com/UN-Other/mvemba-dizolele/ The-UN-in-Congo-The-failure-of-a-peacekeeping-mission

Feeley, R., \& Colin Thomas-Jensen. (2008). Beyond crisis management in eastern Congo. (Strategy Paper, 11 December). Available from <www.kongo-kinshasa.de/ dokumente/ngo/enough_0812.pdf> [Accessed 12 May 2013].

Gil, D., \& G. (1998).Confronting injustice and oppression: Concepts and strategies for social workers. New York, Columbia University Press.

Hansen, T. (2008). Critical conflict resolution theory and practice.Conflict Resolution Quarterly, 25(4), pp. 403-429. Retrieved from: http://onlinelibrary.wiley.com/ doi/10.1002/crq.215/abstract 
International Crisis Group. (2009). Congo: A comprehensive strategy to disarm the FDLR. Africa Report Number 151, 9 July 2009. Retrieved from http://www.crisisgroup. org/ /media/Files/africa/central-africa/dr-congo/151\%20Congo\%20-\%20A\%20 Comprehensive\%20Strategy\%20to\%20Disarm\%20the\%20FDLR\%20-\%20 ENGLISH.pdf

Maeresera, S., \& UfoO, U. (2010). Operationalising the SADC mutual defence Pact: Prospects and constraints, African Security Review, 19 (3), 94-107.

Matsiko, Haggai. (2013, January 20). M23 rebels fear war over sanctions. Retrieved from http://www.independent.co.ug/news/regional-news/7268-m23-congo-rebels-fearwar-over-un-sanctions

Menondji, M.H.A. (2013). Problematic peacekeeping in the DRC: From MONUC to MONUSCO. Why have large-scale international efforts to end the violence in the DRC failed again and again? 4 February. Retrieved from http://thinkafricapress. com/drc/problematic-peacekeeping-drc-monuc-monusco

Nathan, L. (2004). The absence of common values and failure of common security in Southern Africa, 1992-2003.Working paper No. 50. Crisis States Programme. Development Research Centre, London School of Economics, London. Retrieved from http://eprints.lse.ac.uk/28208/1/wp50.pdf

Ngoma, N. (2004). Hawks, doves and penguins: A critical review of SADC military intervention in the DRC. Institute of Security Studies Occasional Paper, 88, 2004. Institute of Security Studies, Pretoria. Retrieved from http://www.issafrica.org/index. php?link_id=3\&slink_id=519\&link_type $=12 \&$ slink_type $=12 \&$ tmpl_id $=3$

Paffenholz, T., \& Christoph, S. (2006). Civil society, civil engagement, and peacebuilding. Social Development Papers: Conflict Prevention and Reconciliation. Working Papers Series No 36, pp. 23-27. Retrieved from http://siteresources.worldbank.org/INTCPR/ Resources/WP36_web.pdf

Perera, S., \& Danielle, B. (2013). Security complexes and complexities in the eastern $D R C$, Paper presented at the $5^{\text {th }}$ European Conference on African Studies: African Dynamics in a multipolar world, 27-29 June, Lisbon. Retrieved from http://www. nomadit.co.uk/ecas/ecas2013/panels.php5?PanelID=2105

Phiri, Gift. (2013, January 18). SADC troops deployed to DRC. Daily News. Retrieved from http://www.dailynews.co.zw/articles/2013/01/18/sadc-troops-deployed-to-drc

Radebe, H. (2013, July 2). SA to send Monusco troops to UN's Congo intervention brigade, Business Day. Retrieved from http://www.bdlive.co.za/national/2013/07/02/sa-tosend-monusco-troops-to-uns-congo-intervention-brigade

Rugeje, A. B., \& Maeresera, S. (2016).The United Nations force intervention brigade: Wither the SADC/ICGLR synchronised peace support efforts in the Eastern Democratic Republic of Congo recurring conflict? Journal of International Studies, 12, 65-79.

Shepherd, B. (2013, November 14). DR Congo: Security Council extends UN mission, intervention force for one year. UN News Center. Retrieved from http://www. chathamhouse.org/media/comment/view/195557

South African National Defence Force. (2000). Statement by SA National Defence Force (SANDF) headquarters: Participation in UN Mission to DRC (MONUC 2). 14 June. Retrieved fromhttp://www.info.gov.za/speeches/2000/0008071010a1005.htm 
Southern African Development Community. (2012). Regional early warning centre. Retrieved from http://www.sadc.int/sadc-secretariat/services-centres/regional-earlywarning-centre

United Nations News Center. (2014, March 26). DR Congo: Security Council extends UN mission, intervention force for one year. Retrieved from http://www.un.org/apps/ news/story.asp?NewsID $=47454 \& \mathrm{Cr}=$ democratic $\& \mathrm{Cr} 1=$ congo\#.U3yCJBUaLcu

United Nations Security Council. (2012). United Nations Security Council (UNSC) S/ RES/2076. Retrieved from http://www.securitycouncilreport.org/un-documents/ democratic-republic-of-the-congo

Zambara, Webster. (2013, January 4). SADC's peace plan faces challenges. Mail and Guardian. Available from <http://mg.co.za/article/2013-01-04-00-sadcs-peace-planfaces-challenges

\section{End Notes}

${ }^{1}$ In the view of an anonymous Great Lakes regional security analyst, the defections of Congolese troops to rebel militias cannot primarily be a result of strategic intelligence crafting by Rwanda and Uganda. The defections have been and are a result of maladministration of the security sector, particularly the military service, by the Congolese government. The Congolese government has not been able to train and retrain its military as well as effectively and efficiently equip and administer its troops so that the Congolese Armed Forces are not found wanting when it comes to the execution of their constitutional obligation, that is, the defence of DRC's territorial integrity (Interview with security analyst, 25 May 2013, Kinshasa. All interviews were conducted by Dr Sadiki Maeresera.).

${ }^{2}$ Non-attributable comment by security analyst on 28 May 2013, Kinshasa. See also International Crisis Group2009:3-11.

${ }^{3}$ Non-attributable comment by security analyst on 28 May 2013, Kinshasa. See also International Crisis Group2009:3-11. At the time of writing this article, Rwanda was reported to have withdrawn all her support for the armed militia fighting the Congolese government. This could have been a result of effective Western diplomacy, particularly the personal direct engagement by the US Secretary of State John Kerry and UK Foreign Minister William Hague. The two diplomats could have played an important role 'in dissuading the Rwandan leadership from any further cross-border adventures'. Other factors such as the reduction in military aid and development assistance could also have resulted in Kigali changing its strategic military deployments and support to rebel militia operating in the Kivus. The authors are indebted to the valuable analysis made by Ben Shepherd, a research fellow with the Chatham House's African Programme. See Shepherd 2013.

4 Non-attributable comment by security analyst on 28 May 2013, Kinshasa.

${ }^{5}$ Non-attributable comment by security analyst on 28 May 2013, Kinshasa. See also International Crisis Group 2009:3-11.

6 Interview with G. Ngoya on 25 May 2013, Kinshasa.

7 Interview with G. Ngoya on 25 May 2013, Kinshasa. 
${ }^{8}$ The ICGLR is made up of member states and co-opted states. The ICGLR member states are Angola, DRC, Zambia, Tanzania, Kenya, Uganda, Congo Republic, Central African Republic, South Sudan and Sudan. The co-opted member states are Namibia, Botswana, Zimbabwe, Malawi, Mozambique, Ethiopia and Egypt. See Boras 2009.

${ }^{9}$ At the time of writing this article, M23 rebel leader Jean Bosco Ntanganda was facing trial at The Hague for crimes against humanity committed by his rebel group. These crimes included rape, mass murders, torture, and forcible recruitment of child soldiers in eastern Congo.

10 See United Nations Security Council 2012.

11 Interview with A. Mulenga on 25 May 2013, Kinshasa.

12 Interview with A. Mulenga on 25 May 2013, Kinshasa.

13 Interview with J. Didier on 25 May 2013. Kinshasa.

14 Interview with A. Mulenga on 25 May 2013. Kinshasa.

${ }^{15}$ The revision of SIPO was aimed at operationalising the SADC protocol on politics, defence and security cooperation. It also sought to provide a five-year implementation framework of the protocol. The major objective of the plan was to create a SADC sub-regional environment that is peaceful, stable and politically secure. Such an environment would ensure the realisation of the SADC sub-region's socio-economic objectives (see also Zambara 2013).

${ }^{16}$ The organ functions as a 'troika' with South Africa and Namibia being the preceding and succeeding chairs respectively.

Museveni was playing a key facilitating role in terms of political dialogue between the DRC government and M23 rebels in Kampala, hence his presence at the SADC summit (see also Zambara 2013).

${ }^{17}$ Museveni was playing a key facilitating role in terms of political dialogue between the DRC government and M23 rebels in Kampala, hence his presence at the SADC summit (see also Zambara 2013).

${ }^{18}$ Non-attributable comment by Great Lakes Regional Political and Military Security Analyst on 28 May 2013, Kinshasa. (see alsoMaeresera and Uzodike 2010:94).

${ }^{19}$ Non-attributable comment by Great Lakes Regional Political and Military Security Analyst on 28 May 2013, Kinshasa.

${ }^{20}$ The extension of its mandate by one year, the peace, security and cooperation framework of MONUSCO, alongside the FIB, allows it to work with the DRC government and all other governments concerned. The tasks within this framework include: establishment of functional, professional and accountable State institutions; protection of civilians; neutralisation of armed groups through the Intervention Brigade in a 'robust, highly mobile and versatile manner and in strict compliance with international law'; monitoring the implementation of the arms embargo, and provision of support to national and international judicial processes in the DRC. From the authors' viewpoint, it is against this background that SADC would take relevant initiatives based on this framework in its endeavours to complement the MONUSCO role, rather than take no action perhaps under the impression that the presence of South African, Tanzanian and Malawian troops as part of the FIB is enough contribution to conflict resolution and peace efforts by the sub-regional body. See also UN News Center 2014.

${ }_{21}$ See South African National Defence Force 2000.

22 Interview with S. Badza on 15 June 2013, Addis Ababa. 